artelogie

\section{Artelogie}

Recherche sur les arts, le patrimoine et la littérature de l'Amérique latine

$13 \mid 2019$

Violeta Parra: authenticité, primitivisme et processus d'exotisme chez les artistes latino-américains.

\title{
Testimonios, Kurt Herdan, 2018, Testimonio Editorial, Santiago.
}

Nathanial Gardner

\section{(2) OpenEdition \\ Journals}

Electronic version

URL: http://journals.openedition.org/artelogie/3363

DOI: 10.4000/artelogie.3363

ISSN: 2115-6395

Publisher

Association ESCAL

Electronic reference

Nathanial Gardner, «Testimonios, Kurt Herdan, 2018, Testimonio Editorial, Santiago. », Artelogie

[Online], 13 | 2019, Online since, connection on 24 September 2020. URL : http://

journals.openedition.org/artelogie/3363; DOI : https://doi.org/10.4000/artelogie.3363

This text was automatically generated on 24 September 2020.

Association ESCAL 


\title{
Testimonios, Kurt Herdan, 2018, Testimonio Editorial, Santiago.
}

\author{
Nathanial Gardner
}

1 A genre brought to the prominence by books such as Biografía de un cimarrón in the 1960s and Me llamo Rigoberta Mechú in the 1980s, 2018's Testimonios: Kurt Herdan is a fresh example that testimonio is alive and well. It is also an example that the genre is also evolving as it lends voice to the smaller, but no lesser important, voices of history.

2 On this occasion the reader the reader meets Kurt Herdan: a European exile in Chile. Born in 1923, the biographical narrative tells of Herdan's youth in the AustroHungarian Empire in the heart of a close-knit Jewish family. Given the time and location of the events, it is easy for the reader to imagine how the story might develop. The government persecutes him and separates him from his family, sending him to a work camp. He hears rumors that his family is exiled to Siberia. Herdan escapes thanks to a Nazi who decides to disobey orders. He flees to Israel where he finds a semblance of stability and studies art. Eventually, the young Kurt returns to Europe and discovers that his family has sought exile in South America. Thanks to kind-hearted organizations, he is granted a visa and given funds to travel to Chile and reunite with his family.

3 Though he had thought to return to Europe after a six-month sojourn in the Southern Cone, Chile opens its arms to Kurt Herdan. It allows him to live as an artist, find love, form a profession and move forward. In some ways, Herdan's is a story of success and escape from trial and persecution. It reminds the reader that life has storms, but those storms can be weathered by holding onto love, family, passion. The narrative is also a reminder that those storms eventually break, and the sun comes out again.

4 Testimonios: Kurt Herdan is also a renovation of the testimonio genre. It combines three genres to tell the story of his life: written narrative, photography and art. All bear testimony of the protagonist's resilience and his ability to create and surround himself with beauty. The photographs give a face to Herdan. We see him as a boy, a young man and as a professional in both Europe and Chile. The stern black and white images break 
into color as we are shown Herdan's present and his perennial interest in art and design.

The bulk of the narrative is Herdan's art. Divided into sections, the authors have given us a sense of the themes: prisoner, politics, couples, society, Kurt and Alicia (his wife), magazines, art, and (strangely enough) hair. Hair aside (which shows us drawings of both men and women with an abundance of the obsession), the themes are roughly divided between love, work and politics.

6 As expected, the prisoner and politics themes are dark and underscore the violence and absurdity of politics under Hitler and Stalin. Some of his most striking paintings are linked to this section. Rough brushstrokes and fierce lines reveal somber images that prompt the reader to ponder topics such as detainment, loss, and death while reminding the reader of difficult experiences and raw emotions.

Importantly, WWII politics are not the only one on his artistic panorama. The No campaign to free Chile from Pinochet politics is also one of the political themes featured in his work. One of the most poignant images is that of page 66 in which we see a toilet full of what appear to be political signs, or possibly flags. Indeed, here we see that his pen has represented long his long-held belief that there is no nationality only "one world and humanity" ( $p$ 15). Curiously, in his artistic portrayal of world there is plenty of love, but there are no children. Any future posterity is not mentioned in the narrative. It is unclear if this is because they did not form a part of his life, or if he simply left them free of his promoted art work.

8 One of the themes that I have yet to seen mentioned regarding this artist and educator is the fusion of individuals. Women blend together with men to form one person. Men stand so close that they appear to fuse into one individual. So close are many individuals that when they speak their nose goes into the open mouth of the other. Even more bizarre are the two-faced individuals who appear among his drawings. In one case the explanation is clear as it is the faces of Hitler and Stalin that share a head: the two sides of the same monster that caused his family's suffering. In the other cases the meaning of this duality is less apparent. I will venture a guess at its meaning. This aspect of the testimonio seems to speak of the dual experience that one lives when in exile. Though nationalized a Chilean, Kurt continued to speak German (in addition to Spanish), his dog was bilingual. He has two sets of roots. Just as his drawings, Herdan has lived a dual life, yet the two experiences blend into one. Hence, the repeated fusion of two realities into one sole individual is simply a representation of the life he has had the privilege to live. The reader is the fortunate individual who is allowed a highly recommendable glimpse of it through his works, art, and photography.

Nathanial Gardner

- University of Glasgow 